\title{
Strategi Guru Dalam Membentuk Akhlak Peserta Didik di Sekolah Alam Islami Mumtaz (SAIM)
}

\author{
Septia Wulandari ${ }^{1}$, Rengga Satria ${ }^{2}$ \\ Fakultas Ilmu Sosial, Universitas Negeri Padang, Indonesia ${ }^{1,2}$ \\ septiawulandari22011999@gmail.com ${ }^{1}$, renggasatria@ fis.unp.ac.id ${ }^{2}$
}

\begin{abstract}
This research aims to find out the teacher's planning in shaping student's akhlak, describing the implementation of teacher strategies in shaping student's akhlak, exposing the evaluation of teacher strategy use in shaping student's akhlak and also exposing whatever support and inhibitory factors in shaping student's akhlak. This research used qualitative methods with case study approaches. The data source was taken through an interview with eight informants consisting of the principal, Islamic religious education teacher, and class teacher Sekolah Alam Islami Mumtaz (SAIM). To strengthen research data the author also retrieves data through observation and documentation. The entire interview data is analyzed by way of collection, reduction, presentation of data and ends with the inference retrieval. The results of the research obtained were first, on the planning aspects that teachers made five steps were to hold meetings, understand the personalities of each student, choose the right strategies, make daily lesson plans, and create a notebook of student behavior change. Second, on the implementation aspects of teacher strategy in shaping the akhlak, there are six ways that are with exemplary, habitation, advice, punishment, gifts, and affection. Third, on the evaluation aspect of strategy use, that is by observing the behavioral changes of student's. Lastly, the aspect of the supporting factors in shaping the akhlak is teacher exemplary, habitation done, and inhibitory factors can be from parents as well as the neighborhood of the friend of the residence.
\end{abstract}

Keywords: Strategy, teacher, akhlak, students

\begin{abstract}
Abstrak
Penelitian ini bertujuan untuk mengetahui perencanaan guru dalam membentuk akhlak peserta didik, mendeskripsikan pelaksanaan strategi guru dalam membentuk akhlak peserta didik, memaparkan evaluasi penggunaan strategi guru dalam membentuk akhlak peserta didik, dan juga memaparkan apa saja faktor pendukung dan penghambat dalam membentuk akhlak peserta didik. Penelitian ini menggunakan metode kualitatif dengan pendekatan studi kasus. Sumber data diambil melalui wawancara dengan delapan orang informan yang terdiri dari kepala sekolah, guru pendidikan agama Islam dan guru kelas Sekolah Alam Islami Mumtaz (SAIM). Untuk memperkuat data penelitian peneliti juga mengambil data melalui observasi dan dokumentasi. Seluruh data wawancara dianalisis dengan cara pengumpulan, reduksi, penyajian data dan diakhiri dengan pengambilan kesimpulan. Hasil penelitian yang didapatkan adalah pertama, pada aspek perencanaan yang dilakukan guru terdapat lima langkah yaitu mengadakan rapat, memahami kepribadian masing-masing peserta didik, memilih strategi yang tepat, membuat daily lesson plan dan membuat buku catatan perubahan perilaku peserta didik. Kedua, pada aspek pelaksanaan strategi guru dalam membentuk akhlak ada enam cara yaitu dengan keteladanan, pembiasaan, nasehat, hukuman, hadiah dan kasih sayang. Ketiga, pada aspek evaluasi penggunaan strategi yaitu dengan mengamati perubahan tingkah laku peserta didik. Terakhir pada aspek faktor pendukung dalam membentuk akhlak adalah keteladanan guru, pembiasaan yang dilakukan dan faktor penghambatnya bisa dari orang tua serta lingkungan teman tempat tinggal.
\end{abstract}

Kata kunci: Strategi guru, akhlak, peserta didik 


\section{Pendahuluan}

Pendidikan merupakan hal yang penting bagi setiap individu. Pendidikan merupakan proses pengubahan tingkah laku seseorang atau kelompok orang dari tidak baik menjadi baik melalui upaya pengajaran dan latihan. Pendidikan juga diartikan sebagai bimbingan secara sadar oleh pendidik terhadap perkembangan jasmani maupun rohani peserta didik menjadi kepribadian yang sempurna (Mahmud, 2011). Selanjutnya dalam Undang-Undang Sistem Pendidikan Nasional No. 20 tahun 2003 menyatakan bahwa:"Pendidikan adalah usaha sadar dan terencana untuk mewujudkan suasana belajar dan proses pembelajaran agar peserta didik secara aktif mengembangkan potensi dirinya untuk memiliki kekuatan spiritual keagamaan, pengendalian diri, kepribadian, kecerdasan, akhlak mulia, serta keterampilan yang diperlukan dirinya, masyarakat, bangsa dan negara" (Indonesia, 2003: 2).

Guru dalam dunia pendidikan memiliki peran yang sangat besar, sehingga antara guru dan pendidikan tidak dapat dipisahkan. Guru merupakan seseorang yang bertanggung jawab untuk memanusiakan manusia, sehingga tugas utama seorang guru adalah mendidik, mengajar, membimbing, mengarahkan, melatih, menilai dan mengevaluasi peserta didiknya dalam pendidikan (Ramayulis, 2013). Dalam Islam guru adalah profesi yang sangat mulia, karena guru tidak hanya sebagai pengajar tetapi juga sebagai pendidik. Seseorang yang menjadi guru tidak hanya karena ia telah memenuhi kualifikasi keilmuan dan akademis saja, tetapi yang lebih penting adalah memiliki akhlak yang mulia. Sebab guru seringkali menjadi panutan bagi peserta didik dan juga masyarakat.

Persoalan akhlak selalu menjadi masalah sejak dahulu sampai sekarang. Pada zaman sekarang dengan kecanggihan teknologi yang berkembang pesat, akhlak peserta didik semakin merosot. Jika peserta didik tidak diberikan pendidikan yang tepat maka mereka akan terjerumus kearah yang tidak baik. Apalagi peserta didik Sekolah dasar (SD) merupakan masa-masa yang sangat menentukan. Permasalahan yang sering terjadi di lingkungan saat ini yaitu anak tidak sholat lima waktu, melawan kepada kedua orang tua, tidak sopan kepada orang yang lebih tua, berkata-kata kotor, suka berkata bohong, menjahili teman, merusak lingkungan, menganiaya binatang dan lain sebagainya. Oleh karena itu apabila anak dibiarkan tumbuh dan berkembang secara alamiah tanpa bantuan pendidikan, sangat memungkinkan anak kehilangan arah dalam menjalani kehidupan menuju kebaikan dan kebenaran. Sebab dalam setiap diri manusia punya sarana kemampuan untuk menerima pengaruh yang menyesatkan atau menyelamatkan (Harahap, 2016).

Pembentukan akhlak peserta didik diperlukan kerja sama seluruh warga sekolah. Seperti adanya kerja sama antara kepala sekolah dengan semua guru, baik guru Pendidikan Agama Islam maupun guru mata pelajaran lain dan guru kelas. Selain itu juga diperlukan kerjasama antara sekolah dengan orang tua maupun dengan masyarakat. Dengan terciptanya kerja sama antara seluruh warga sekolah, orang tua dan masyarakat pembentukan akhlak peserta didik akan berjalan dengan baik. Karena setiap guru mengharapkan anak didiknya menjadi manusia yang tepat guna, berakhlakul karimah, mempunyai kecerdasan intelektual, spritual, emosional, dan sosial (Kalsum, 2018). 
Pembentukan manusia yang berakhlak mulia merupakan kegiatan yang melalui proses panjang karena akhlak tidak bisa tumbuh dengan tiba-tiba. Dalam proses pembentukan akhlak itulah diperlukan strategi, metode dan teknik/ prosedur yang benar (Syamsu, 2016). Berdasarkan hasil observasi awal yang dilakukan peneliti pada tanggal 11 januari 2021, peneliti menemukan bahwa Sekolah Alam Islami Mumtaz (SAIM) merupakan sekolah pertama dan satu-satunya di Kabupaten Lima Puluh Kota dan Kota Payakumbuh. Tolak ukur kurikulum di sekolah ini adalah integritas akhlak, logika ilmiah, leadership (kepemimpinan) dan entrepreneurship (kewirausahaan). Oleh karena itu perlu dilakukan penelitian tentang Strategi Guru dalam membentuk Akhlak Peserta Didik di Sekolah Alam Islami Mumtaz (SAIM).

\section{Tinjauan Pustaka}

Akhlak merupakan kondisi atau sifat yang telah meresap dalam jiwa dan menjadi kepribadian sehingga timbullah berbagai macam perbuatan secara spontan dan mudah tanpa dibuat-buat dan tanpa memerlukan pikiran (Ma'sumah, 2020). Selanjutnya menurut Saebani dan Hamid (2010) secara substansial akhlak memiliki lima ciri yaitu: pertama, akhlak merupakan perbuatan yang telah tertanam kuat dalam jiwa seseorang sehingga menjadi kepribadian. Kedua, akhlak merupakan perbuatan yang dilakukan dengan mudah tanpa pemikiran terlebih dahulu. Ketiga, akhlak merupakan perbuatan yang timbul dari dalam diri orang yang mengerjakannya, tanpa adanya paksaan atau tekanan dari luar. Keempat, akhlak merupakan perbuatan yang dilakukan dengan sesungguhnya, bukan main-main atau karena bersandiwara. Kelima, akhlak (khususnya akhlak yang baik) merupakan perbuatan yang dilakukan dengan ikhlas semata-mata karena Allah SWT, bukan karena ingin mendapatkan pujian.

Beberapa pendapat di atas dapat peneliti simpulkan bahwa akhlak adalah segala tingkah laku, perangai, tabiaat, kebiasaan yang sudah melekat dalam diri seseorang sehingga dalam perbuatannya tidak perlu melakukan pertimbangan-pertimbangan terlebih dahulu. Akhlak merupakan ukuran kepribadian seorang muslim. Akhlaknya seorang muslim adalah Alquran dan Hadits. Seseorang yang berkepribadian sesuai dengan Alquran dan Hadits berarti ia adalah seseorang yang berakhlak mulia. Allah SWT mengutus Nabi Muhammad SAW sebagai penyempurna akhlak yang mulia (Rosyidah, 2019). Sebagaimana sabda Rasulullah SAW yang berbunyi:

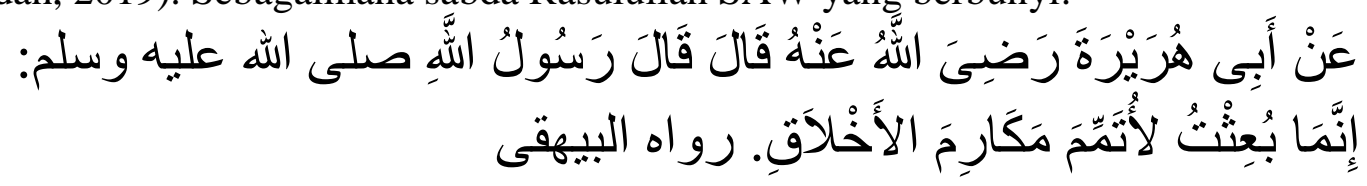

Artinya: "Dari Abu Hurairah RA. meriwayatkan bahwa Rasulullah SAW. bersabda: Sesungguhnya aku diutus untuk menyempurnakan kemuliaan akhlak (HR. alBayhaqiy) "(Pulungan, 2018).

Ruang lingkup akhlak meliputi seluruh kehidupan manusia itu sendiri. Menurut Makbuloh (2015) ruang lingkup akhlak terdiri dari 1) Akhlak terhadap Allah SWT, 2) Akhlak terhadap Rasulullah SAW, 3) Akhlak terhadap diri sendiri, 4) Akhlak terhadap keluarga, 5) Akhlak terhadap masyarakat, dan 6) Akhlak terhadap lingkungan. Selanjutnya menurut Rosyidah (2019) akhlak dipengaruhi oleh beberapa faktor yaitu a) Adat atau kebiasaan yaitu dibentuk melalui praktek, kebiasaan, mengulangi perbuatan 
itu secaraterus-menerus. b) Keturunan yaitu sifat-sifat orang tua akan berpindah kepadaanak dan cucunya. Sifat yang diwariskan tidak hanya yang bisa dilihat saja seperti bentuk fisik, tetapi juga kecerdasan, kepribadian dan lain-lain. c) Lingkungan yaitu masyarakat yang berada disekitar kita dan hidup bersama kitasehari-harinya. d) Naluri yaitu seperangkat tabiat yang dibawa manusia sejak lahir tanpa dipelajariterlebih dahulu.

Strategi diperlukan guru dalam membentuk akhlak peserta didik. Strategi pendidikan merupakan sebuah rangkaian perilaku pendidikan yang disusun secara terencana dan sistematis untuk menginformasikan, mentransformasikan serta menginternalisasikan nilai-nilai Islam. Dengan adanya strategi pendidikan, peserta didik akan lebih terarah sehingga dapat membentuk kepribadian Muslim seutuhnya (Zamroni, 2017).

Strategi yang dapat diterapkan guru dalam pembentukan akhlak kharimah menurut Maisyanah et al. (2020) di antaranya kegiatan pembiasaan yang berarti melakukan suatu perbuatan secara terus-menerus. Sebab akhlak mulia tidak terbentuk secara instan atau cepat. Contoh sederhana dari pembiasaan yaitu selalu membaca basmallah setiap kali akan mengerjakan sesuatu dan mengucapkan hamdalah setelah melakukan pekerjaan.

Guru harus menjadi teladan yang baik bagi peserta didik. Dengan begitu peserta didik dengan sendirinya akan meniru perilaku guru meraka. Sebelum memerintahkan peserta didik untuk selalu membuang sampah pada tempatnya, seorang guru harus terlebih dahulu melakukan hal tersebut. Jika guru mereka saja tidak membuang sampah pada tempatnya, bagaimana mungkin peserta didik dengan sendirinya membuang sampah pada tempatnya.

Memberikan penghargaan atau apresiasi dimana peserta didik yang selalu melakukan kebaikan dan selalu menaati peraturan yang telah ditetapkan hendaklah diberikan hadiah, penghargaan atau apresiasi. Pemberian apresiasi diharapkan agar peserta didik senang dan semangat dalam melakukan suatu perbuatan setiap harinya. Lama-kelamaan dengan dilakukannya setiap hari akan menjadi kebiasaan, sehingga pada akhirnya peserta didik tidak lagi mengharapkan imbalan atas perbuatan yang mereka lakukan.

Menerapkan peraturan serta hukuman kepada peserta didik yaitu dengan adanya peraturan serta memberikan hukuman kepada peserta didik yang melanggarnya. Peserta didik akan malu untuk melanggar aturan tersebut. Jika peserta didik melanggar aturan sekali maka ditegur dan dinasehati saja, tetapi jika peserta didik melanggar aturan lebih dari tiga kali maka diberikan hukuman agar peserta didik tidak mengulangi kesalahannya.

Sekolah Alam merupakan sekolah dengan konsep pendidikan berbasis alam semesta. Konsep tersebut diambil dari nilai-nilai Alquran dan Hadits Rasulullah SAW, yang menyatakan bahwa hakikat penciptaan manusia adalah untuk menjadi khalifah di muka bumi (Fillah, 2018). Sebagaimana Firman Allah SWT dalam QS. al-Baqarah 2: 30 yang berbunyi: 


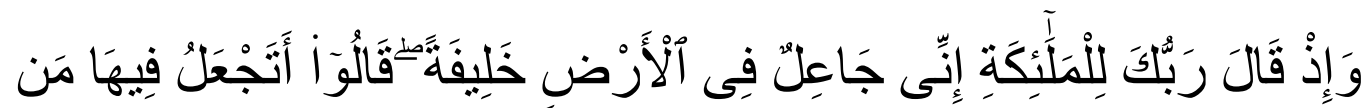

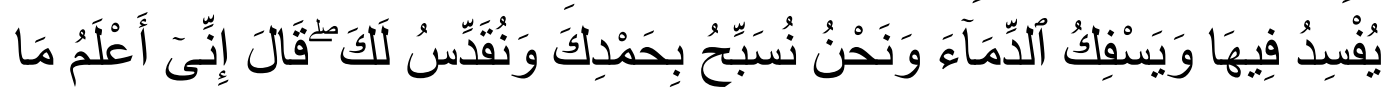 لَا تَعْلَمُونَ}

Artinya: "Dan (ingatlah) ketika Tuhanmu berfirman kepada para malaikat, "Aku hendak menjadikan khalifah di bumi." Mereka berkata, "Apakah Engkau hendak menjadikan orang yang merusak dan menumpahkan darah di sana, sedangkan kami bertasbih memuji-Mu dan menyucikan-Mu ?" Dia berfirman, "Sungguh, Aku mengetahui apa yang tidak kamu ketahui."

\section{Metode Penelitian}

Penelitian ini menggunakan metode kualitatif dengan pendekatan studi kasus. Studi kasus merupakan penelitian yang mendalam tentang individu, kelompok dan sebagainya dalam periode tertentu (Sugiarto, 2017). Informan dalam penelitian ini dipilih menggunakan teknik purposive sampling, yaitu teknik pengambilan data didasarkan pada tujuan dan pertimbangan tertentu (Sugiyono, 2008). Pada penelitian ini data primer peneliti ambil dari kepala sekolah, guru Pendidikan Agama Islam dan guru kelas di Sekolah Alam Islami Mumtaz (SAIM) Mungka Tangah Kecamatan Mungka. Sedangkan data sekunder peneliti ambil dari dokumen-dokumen sekolah, catatancatatan guru mengenai tingkah laku peserta didik, foto-foto kegiatan keagamaan yang telah dilakukan dan lain sebagainya. Teknik pengumpulan data dalam penelitian ini yaitu melalui wawancara, observasi dan dokumentasi. Kemudian data dianalisis dengan langkah pengumpulan, reduksi, penyajian data dan menarik kesimpulan. Cara yang digunakan peneliti dalam menguji keabsahan data yaitu menggunakan triangulasi. Triangulasi merupakan sebuah cara menguji keabsahan data dengan memanfaatkan berbagai sumber, berbagai cara dan berbagai waktu dari data yang telah dikumpulkan (Sugiyono, 2008).

\section{Hasil dan Pembahasan}

Peneliti melakukan penelitian di Sekolah Alam Islami Mumtaz (SAIM) yang beralamat di Jorong Mungka Tangah, Kenagarian Mungka, Kecamatan Mungka, Kabupaten Lima Puluh Kota. Peneliti menemukan bahwa perencanaan yang dilakukan kepala sekolah dalam pembentukan akhlak peserta didik adalah mensosialisasikan bagaimana kurikulum integrasi akhlak, apa saja akhlak yang dibentuk dan apa saja kegiatan-kegiatan dalam pembentukan akhlak. Sebagaimana kutipan wawancara dengan informan 1 selaku kepala SAIM, diwawancarai tanggal 25 Maret 2021 pada jam 11.30 sebagai berikut:

"Perencanaan pertama yang Abi lakukan yaitu dengan membuat komitmen dengan guru-guru tentang membentuk akhlak anak. Setiap awal semester kami selalu mengadakan diskusi terkait sekolah alam. Abi tidak membatasi guru-guru di sini berkreasi, selama hal itu baik maka Abi persilahkan. Semua guru-guru di sini dekat dengan anak, karena salah satu syarat menjadi guru di sini yaitu sayang anak-anak. Dekatnya guru dengan anak maka mereka akan mengetahui cara-cara yang tepat 
dalam menghadapi setiap anak. Kegiatan pembentukan akhlak sudah Abi diskusikan dengan teman-teman sebelum sekolah beroperasi. Kami juga mensosialisasikannya ke guru-guru SAIM, jadi guru-guru tinggal menjalankannya..."

Hal yang perlu direncanakan guru dalam membentuk akhlak adalah pertama dengan memahami perilaku masing-masing peserta didik. Selanjutnya memilih strategi yang digunakan dalam pembentukan akhlak. Setiap peserta didik itu berbeda-beda, ada yang mudah dibentuk dan ada yang sulit. Peserta didik yang sulit dibentuk inilah diperlukan strategi yang ekstra, dan bermacam-macam strategi. Kemudian guru membuat daily lesson plan serta menyiapkan catatan-catatan perubahan tingkah laku peserta didik. Sebagaimana kutipan wawancara dengan informan 2 selaku guru PAI dan guru tahfidz diwawancarai tanggal 24 Maret 2021 pada jam 09.18 sebagai berikut:

“...Seorang guru harus mendalami pribadi masing-masing anak. Oleh karena itu guru harus menghabiskan waktu dengan anak. Guru juga harus memilih strategi yang tepat dalam membentuk akhlak anak. Kegiatan pembentukan akhlak anak sudah ditetapkan Abi Hamid dan kawan-kawan termasuk ummi juga, jadi kita tinggal menjalankannya saja."

Berdasarkan hasil wawancara dengan informan dapat diketahui bahwa strategi yang digunakan guru dalam pembentukan akhlak peserta didik di Sekolah Alam Islami Mumtaz (SAIM) Mungka Tangah Kecamatan Mungka yaitu dapat dilihat pada gambar di bawah ini:

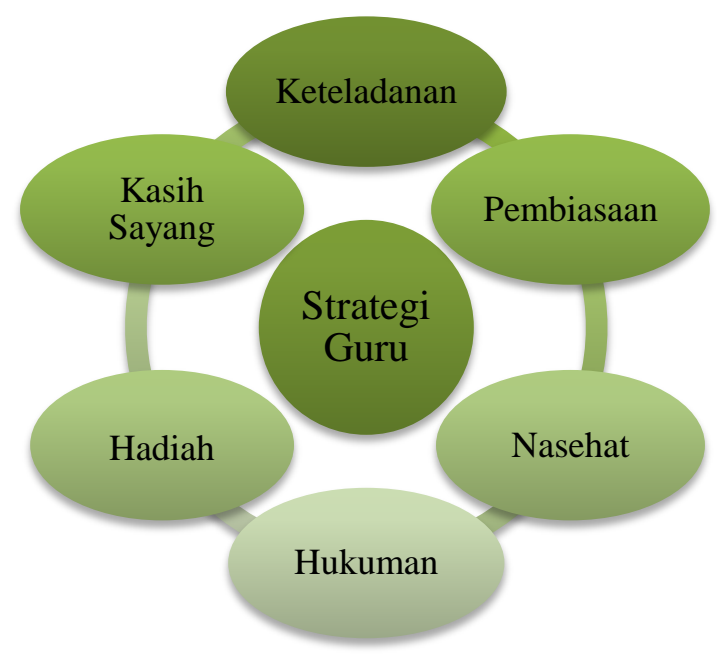

\section{Gambar 1.Strategi Guru dalam Pembentukan Akhlak Peserta Didik di Sekolah Alam Islami Mumtaz (SAIM)}

Dari hasil wawancara dengan informan 3 selaku guru kelas 1 (M. Natsir), tanggal 29 Maret 2021 pada jam 09.00 yang mengatakan:“...Guru seringkali dijadikan contoh, sebab peserta didik akan mencontoh tingkah laku gurunya..." Dikuatkan juga oleh informan 8 selaku guru kelas 5 (Buya Hamka), tanggal 1 April 2021 pada jam 09.22: “...Keteladanan, guru harus bersikap sesuai dengan Alquran dan Hadits...”

Peneliti menyimpulkan bahwa strategi pertama yang digunakan guru-guru dalam pembentukan akhlak peserta didik di Sekolah Alam Islami Mumtaz (SAIM) Mungka Tangah Kecamatan Mungka adalah keteladanan. Dari observasi yang peneliti lakukan keteladanan yang dicontohkan guru antara lain berpakaian sesuai syariat Islam, berkata- 
kata sopan, jujur, ramah, saling menghormati, disiplin, selalu menjaga kebersihan, merawat tanaman, menyayangi hewan, dan masih banyak lagi.

Ketika melakukan sesuatu secara terus-menerus dan konsisten maka akan menjadi kebiasaan bagi siapapun. Hal ini dikuatkan oleh Maisyanah et al. (2020) yang berpendapat pembiasaan berarti melakukan suatu perbuatan secara terus menerus. Sebab akhlak mulia tidak terbentuk secara instan atau cepat.

Berdasarkan hasil wawancara dengan informan 5 selaku guru kelas 2 (M.Hatta), tanggal 30 Maret 2021 pada jam 11.15 mengatakan:“...ketika kita selalu menyuruh melakukan sesuatu secara terus-menerus seperti membaca doa sebelum dan sesudah melakukan sesuatu, mengucapkan salam saat memasuki ruangan, berkata yang baik, buang sampah pada tempatnya, dll. Maka diharapkan nantinya peserta didik dengan sadar diri mengerjakan apa yang telah dibiasakan tersebut..."

Hal di atas juga didukung oleh hasil wawancara dengan informan 7 selaku guru kelas 4 (Imam Bonjol), tanggal 31 Maret 2021 pada jam 13.52 yang mengatakan:

“...dengan melaksanakan kegiatan secara terus-menerus selama di sekolah. Lamakelamaan akan menjadi kebiasaan bagi anak..."

Berdasarkan hasil wawancara dan observasi peneliti di Sekolah Alam Islami Mumtaz (SAIM) Mungka Tangah Kecamatan Mungka peserta didik setiap hari melakukan kegiatan yaitu muraja`ah hafalan, menambah hafalan one day one ayat, shalat sunnah dhuha berjamaah, membaca spirit islam, shalat wajib zuhur dan asar berjamaah di sekolah, berzikir dan berdoa setelah sholat, membaca doa sebelum dan sesudah melakukan sesuatu, berkebun, dan lain-lain.

Nasehat yang disampaikan secara tulus kepada peserta didik akan diserap oleh peserta didik. Sebagaimana menurut Zamroni (2017) bahwa nasehat yang tulus membekas dan berpengaruh, jika memasuki hati yang bening, hati terbuka, akal yang bijak.

Berdasarkan hasil wawancara dan observasi yang telah peneliti lakukan nasehat yang disampaikan guru di Sekolah Alam Islami (SAIM) Mungka Tangah Kecamatan Mungka adalah melalui spirit Islam dan juga melalui kisah-kisah Nabi dan Rasul, sahabat Rasul, dll. Sebagaimana yang dikatakan informan 4 selaku guru kelas 2 (Rohana Kudus), tanggal 29 Maret 2021 pada jam 11.20 sebagai berikut: “...ketika peserta didik nakal maka dinasehati dengan spirit Islam 'yang menganiaya akan teraniaya'. Jika peserta didik marah-marah maka dibacakan 'janganlah kamu marah dan bagimu surga'. Nasehat ini juga bisa dilakukan dengan membacakan kisah-kisah Nabi dan Rasul sebelum mereka tidur siang..."

Hukuman diberikan ketika peserta didik berulang kali melakukan kesalahan yang sama. Setelah diberikan teguran masih juga mengulanginya, saat itulah hukuman diberikan. Berdasarkan hasil wawancara dan observasi yang telah peneliti lakukan ketika peserta didik main-main waktu mengulang hafalan dan waktu melaksanakan shalat maka hukuman yang diberikan biasanya dengan menyuruh peserta didik berdiri dan mengulang hafalan sendiri. Kemudian dalam hal shalat peserta didik diperintahkan mengulang shalat sampai benar. Sebagaimana yang dikatakan informan 6 selaku guru kelas 3 (Rasuna Said), tanggal 30 Maret 2021 pada jam 09.16: “...ketika ada yang main-main dalam sholat maka disuruh mengulang shalatnya sampai betul...” 
Hal di atas dikuatkan oleh informan 7 selaku guru kelas 4 (Imam Bonjol), tanggal 31 Maret 2021 pada jam 13.52 yang mengatakan:“...pemberian hukuman biasanya dilakukan ketika nasehat tidak lagi mempan bagi anak. Setelah mendapatkan hukuman beberapa kali biasanya mereka sudah jera dan tidak mengulangi kesalahan yang sama lagi..."

Selain memberikan hukuman ada juga memberikan hadiah. Hadiah diberikan kepada peserta didik yang melaksanakan perintah dengan benar dan sungguh-sungguh. Hadiah tidak hanya berupa barang tetapi juga berupa gerakan badan, mimik wajah. Berdasarkan hasil wawancara dan observasi yang peneliti lakukan peserta didik diberikan hadiah ketika mereka mengerjakan yang disuruh dengan baik, seperti menyalin surah Alquran ke dalam buku catatan dengan rapi, menjaga kebersihan, hafalannya lancar.

Kasih sayang yang tulus akan dirasakan oleh peserta didik. Ketika guru mereka memberikan kasih sayang, mereka akan merasa nyaman. Peserta didik biasanya akan terbuka kemudian akan menceritakan hal-hal kecil sekalipun kepada gurunya. Ketika peserta didik merasa nyaman dengan gurunya, mereka akan mendengarkan apa yang dikatakan oleh gurunya. Sebagaimana yang dikatakan informan 2 selaku guru PAI dan guru tahfidz tanggal 24 Maret 2021 pada jam 09.18 bahwa: “...karena kasih sayang kita yang tulus mereka akan terbuka dengan kita dan mereka akan mendengarkan apa yang kita katakan..."

Diperlukan perhatian setiap harinya walau terkadang peserta didik suka lupa, karena usia Sekolah dasar masih labil. Berdasarkan hasil wawancara dan observasi peneliti bahwa semua guru yang ada di Sekolah Alam Islami Mumtaz (SAIM) Mungka Tangah Kecamatan Mungka memberikan kasih sayang kepada semua peserta didik tanpa membeda-bedakan peserta didik yang satu dengan yang lainnya.

Pelaksanaan strategi di atas berjalan dengan lancar, walaupun terkadang juga ada kendala-kendala yang dihadapi guru. Strategi yang satu dengan strategi yang lain saling melengkapi. Jika peserta didik tidak mempan dengan strategi keteladanan dan pembiasaan maka digunakanlah strategi nasehat. Jika nasehat tidak masuk juga maka diberi hukuman. Biasanya setelah peserta didik diberikan hukuman berkali-kali mereka akan berubah.

Tolak ukur keberhasilan pembentukan akhlak peserta didik di Sekolah Alam Islami Mumtaz (SAIM) Mungka Tangah Kecamatan Mungka yaitu ketika ada perubahan tingkah laku peserta didiknya ke arah yang lebih baik. Hal ini dapat diperhatikan dari keseharian peserta didik dan laporan dari orang tua bagaimana sikap mereka di rumah. Sebagaimana menurut Ainiyah (2013), evaluasi dari keberhasilan pendidikan karakter tidak dapat dinilai dengan tes formatif atau sumatif yang dinyatakan dalam skor. Tetapi tolak ukur keberhasilan pendidikan karakter adalah terbentuknya peserta didik yang berkarakter, berakhlak, berbudaya, santun yang diterapkan dalam kehidupan sepanjang hayatnya. Hal ini juga berlaku dalam pembentukan akhlak peserta didik.

Faktor pendukung dan faktor penghambat dalam pembentukan akhlak peserta didik saling keterkaitan. Pertama faktor dari dalam, ketika dari dalam diri anak sudah 
tertanam sikap baik maka akan mudah jika diarahkan dan sebaliknya. Begitupun ketika peserta didik berasal dari keluarga yang paham agama maka akan mudah juga diarahkan karena sudah ada bekal dan sebaliknya ketika peserta didik berasal dari keluarga yang kurang paham agama maka guru akan kesulitan untuk mengarahkannya.

Kedua faktor dari luar yaitu lingkungan sekolah dan lingkungan teman. Karena di Sekolah Alam Islami Mumtaz (SAIM) Mungka Tangah Kecamatan Mungka guru-guru memberikan keteladanan dan lingkungannya baik maka lama-kelamaan peserta didik yang akhlaknya kurang baik akan berubah, dan juga perlu dukungan dari orang tua. Selanjutnya lingkungan teman di rumah jika baik maka peserta didik akan baik dan sebaliknya ketika teman-teman mereka di rumah kurang baik seperti suka berkata-kata kotor maka sedikit banyaknya anak akan terpengaruh.

\section{Simpulan}

Simpulan dari penelitian ini yaitu perencanaan yang dilakukan guru dalam pembentukan akhlak peserta didik yaitu pertama kepala sekolah mensosialisasikan dahulu bagaimana kurikulum integrasi akhlak tersebut, apa saja akhlak yang dibentuk dan apa saja kegiatan-kegiatan dalam pembentukan akhlak. Setiap guru memahami perilaku masing-masing peserta didik. Selanjutnya memilih strategi yang digunakan dalam pembentukan akhlak. Kemudian guru membuat daily lesson plan serta menyiapkan catatan-catatan perubahan tingkah laku peserta didik.

Strategi yang digunakan guru dalam pembentukan akhlak peserta didik yaitu keteladanan, pembiasaan, nasehat, hukuman, hadiah, dan kasih sayang. Dalam pelaksanaannya berjalan lancar, kadang-kadang juga ada kendala karena peserta didik usia sekolah dasar masih labil. Tahap evaluasi penggunaan strategi guru yaitu dengan melihat keseharian peserta didik. Ketika peserta didik berubah kearah yang lebih baik berarti strategi yang digunakan berhasil. Jika masih ada peserta didik yang sulit berubah maka diperlukan usaha ekstra dalam menerapkan strategi pembentukan akhlak peserta didik.

Terakhir faktor pendukung dalam pembentukan akhlak peserta didik di Sekolah Alam Islami Mumtaz (SAIM) Mungka Tangah Kecamatan Mungka adalah keteladanan guru, pembiasaan yang dilakukan sekolah dan orang tua yang mendukung program SAIM. Sedangkan faktor penghambatnya yaitu bisa dari orang tua, lingkungan teman peserta didik saat di rumah, smartphone, dll.

\section{Referensi}

Ainiyah, N. (2013). Pembentukan karakter melalui pendidikan agama Islam. Al-Ulum, $13(1), 25-38$.

Fillah, A. M. (n.d.). Pembelajaran Pendidikan Agama Islam (Pai) Berbasis Alam Untuk Membentuk Karakter Religius Di Sekolah Alam Tangerang.

Harahap, M. (2016). Esensi Peserta Didik dalam Perspektif Pendidikan Islam. Jurnal Pendidikan Agama Islam Al-Thariqah, 1(2), 140-155.

Indonesia, P. R. (2003). Undang-undang Republik Indonesia nomor 20 tahun 2003 tentang sistem pendidikan nasional. Departemen Pendidikan Nasional. 
Kalsum, U. (2018). Strategi Guru Akidah Akhlak dalam Menanamkan Karakter Islami Peserta Didik MTs. Guppi Samata Gowa. Inspiratif Pendidikan, 7(1), 76-95.

Ma'sumah, I. (2020). Implementasi pembelajaran kitab Taisîrul Khollâq Fî 'Ilmil Akhlaq dalam pembentukan akhlak peserta didik di MTs Islamiyah Tanggulangin Sidoarjo. UIN Sunan Ampel Surabaya.

Mahmud, P. P. I. (2011). Pustaka Setia. Bandung.

Maisyanah, M., Syafa'ah, N., \& Fatmawati, S. (2020). Strategi Guru Pendidikan Agama Islam Dalam Membentuk Akhlakul Karimah Peserta Didik. At-Ta'dib: Jurnal Ilmiah Prodi Pendidikan Agama Islam, 15-30.

Makbuloh, D. (2015). Pendidikan Agama Islam: Arah Baru Pengembangan Ilmu dan Kepribadian di Perguruan Tinggi. Rajawali Pers.

Pulungan, A. (2018). Implementasi Pendidikan Karakter Berbasis Pesantren Di Ma'had Al-Jami'ah Universitas Islam Negeri Sumatera Utara. Tazkiya, 7(2).

Ramayulis, H. (2013). Profesi dan etika keguruan. Jakarta: Kalam Mulia.

Rosyidah, E. (2019). Upaya Guru Pendidikan Agama Islam dalam Pembentukan Akhlak Peserta Didik di TPQ Al-Azam Pekanbaru. Al-Idarah: Jurnal Kependidikan Islam, 9(2), 180-189.

Saebani, B. A., \& Hamid, A. (2010). Ilmu Akhlak. Bandung: Pustaka Setia.

Sugiarto, E. (2017). Menyusun Proposal Penelitian Kualitatif: Skripsi dan Tesis: Suaka Media. Diandra Kreatif.

Sugiyono. (2008). Metode penelitian pendidikan:(pendekatan kuantitatif, kualitatif dan $R \& D)$. Alfabeta.

Syamsu, S. (2016). Strategi Pembelajaran Pendidikan Agama Islam Antisipasi Krisis Akhlak peserta Didik Pada SMA Negeri di Palopo. INFERENSI.

Zamroni, A. (2017). Strategi Pendidikan Akhlak Pada Anak. Sawwa: Jurnal Studi Gender, 12(2), 241-264. 